\title{
The empirical study of the effect of audit quality on audit charge_through studies on accounting firms auditing public companies in 2012
}

\author{
Zhongfu $\mathrm{Yu}^{1, \mathrm{a}}$, Shuyuan Tang ${ }^{2, \mathrm{~b}}$ and Meng Zhang ${ }^{3, \mathrm{c}}$ \\ ${ }^{1}$ North China Electric Power University, Beijing, China \\ ${ }^{2}$ North China Electric Power University, Beijing, China \\ ${ }^{3}$ Beijing City University, Beijing, China \\ ayu_zhongfu@163.com, b tsy306@126.com, '1697349157@qq.com
}

Key words: audit quality; audit charge; factor analysis; empirical study

\begin{abstract}
Considered as a kind of compensation that audit beneficiaries pay audit providers, audit charge is one of the factors causing changes of audit quality. In order to analyze and discuss the relationship between audit quality and audit charge, the article applies factor analysis and multiple regression analysis based on 44 accounting firms and audit reports of 2,438 public companies in 2012. The result shows that audit quality has significant positive correlation with audit charge.
\end{abstract}

\section{Introduction}

The fairness and legitimacy of a specific financial statement are mainly based on the audit reports made by certified public accountants. Since 2001, such financial fraud cases as U.S. Companies Enron, Xerox, Merck and Chinese companies Zheng Bai-wen, Kelon, have aroused an increasing suspiciousness on ethics of certificated public accountants and the quality of the audit. At present, China's legal system is unsound, which may require greater needs of external audit institutions to supervise as well as monitor companies. However, the needs of hiring external audit institution can result in the loss of independence of the audit as well as affect the audit quality. The accounting firms faces many tradeoffs, one of which is that on the one hand, in order to get their high audit fees, accounting firms have to violate accounting standards and issue unreasonable audit reports that satisfy customers, which will definitely affect the audit quality. On the other hand, in order to occupy or expand their market shares, most accounting firms will adopt low price strategy, which will directly cause audit quality down. According to the Free Market Pricing Theory, price reflects quality, audit charge should be proportional to audit quality, but as the effect of unhealthy external market mechanism, this relationship becomes more complicated.

In 2001, China Securities Regulatory Commission issued "Standard Q\&A 6 on rules of public companies information disclosure----accounting firms compensation and disclosure" requiring public companies to disclose accounting firms' compensation as an important issue in annual reports. This document provides a dimension to well measure the audit charges and audit quality of different accounting firms and different companies. However, audit quality is an abstract conception which is difficult to measure; also evaluation criteria of various countries are also different from each other. Therefore, how to measure audit quality properly, so as to research the relationship between audit quality and audit charges in a direct way, has been a general concern in academic fields.

\section{Literature review and study assumptions}

There are mainly two opinions on this issue in academic fields, one of which is that audit quality and audit charge are independent from each other, the other is that they are positively correlated. Lennox.C. (2003) did research on the relationship between audit quality and audit charges by taking 2000-2001 listed companies on Shanghai Stock Exchange as samples. The result shows that there was no significant relation among audit fees and accrued profits that are controllable. The empirical study made by Copley etal.(1993) shows that the audit quality and audit fees were positively related, that is to say the better the quality of audit products provided by accounting firms is, the higher audit charge is. Yao Huaying (2010) took Shanghai stock exchange market index 180 as samples, reached the conclusion that total auditing costs are negatively correlated with the absolute value of manipulative accrued profits. Zhang Shuping (2012) held the opinion that the higher audit charge is, 
the better audit quality is.

Through literature study and review, this article finds that there are few adopting empirical studies that can do research on the audit quality and audit. The majority of literatures are finished based on the theoretical illustration, and they lack new exploration and attempts on the argument. Of the articles which have empirical studies on audit quality measures, the measure tends to be simple or complicated, lacking studies on extents of different factors. This article hopes to apply a completely new method--factor analysis to quantify and make more comprehensive evaluation of audit quality. The result will be implemented by the significant correlation test, through this way we can probe the relationship between audit quality and audit charge.

The article thinks that when there are high audit charges, accounting firms may spend more manpower, material and financial resources on auditing, the quality of audit reports will improve accordingly. Therefore, we assume that the audit quality of accounting firms and the audit charges are significantly positively correlated.

\section{Research design}

Sample selection. Samples in this article are audit charges of accounting firms participating in the audit of public companies in 2012 and related variables affecting audit quality in different accounting firms. Relevant data are from the database of Guotaijun'an, management information system of Chinese certified public accountants industry and "Information of Top 100 accounting firms in 2013"'issued by Chinese Institute of Certified Public Accountants. We removed ST, *ST and PT companies, and got 2438 valid samples, totaling 44 accounting firms ( Zhong Lei accounting firm was removed because of Wanfu Biotechnology Agricultural Development Co. Financial fraud). All the data analysis and processing are finished in SPSS 21.0.

Variables explanation. The article treats the total amount of audit as audit charges. All variable indicators influencing audit quality are as follows: (1) registered capital (registered capital of accounting firms); (2) organizational form, limited liability or general partnership. As classified variable, the article encodes limited liability form as 1 , general partnership form as 2 taking the results of analysis of literature review into consideration. The higher the score is, the better audit quality is. (3) The number of branches. (4) Number of certificated public accountants excludes those in branches; (5) The ratio of 40-60 years old certificated public accountants excludes those accountants in branches; (6) The ratio of accountants with bachelor degrees or above excludes those accountants in branches; (7) The ratio of standard unqualified audit opinions; (8) The proportion of audit amount of full-year operating revenues is treated as indicator of importance of customers.

Basic ideas in statistics analysis Exploratory factor analyses are used on 8 variable factors affecting audit quality, then a comprehensive evaluation score of audit quality is formed. The article uses this score replacing audit quality of accounting firms, total audit fees replacing audit charge, then put them into a multiple regression analysis, in order to find the underlying relationship between audit quality and audit charge.

\section{Empirical results and analysis}

The results of factor analysis. Exploratory factor analysis steps are as follows: (1) review the relevant information between variable indicators, judge whether it's suitable to apply the factor analysis by KMO and Bartlett test of sphericity; (2) When extracting factor we select eigenvalues greater than 1; (3) when rotating factors we use the maximum variance method; (4) calculate sample scores on each factor.

(1)Statistical test before factor analysis

Before factor analysis, we need to do the correlation tests on sample data in order to judge whether it's suitable to use factor analysis. ( See Table 1 )

Table $1 \mathrm{KMO}$ and Bartlett's sphericity test

\begin{tabular}{|c|c|c|}
\hline KMO Sampling adequacy test & & 0.7 \\
\hline \multirow{3}{*}{ Bartlett's sphericity test } & Approximate chi-square value & 103.778 \\
\cline { 2 - 3 } & Degree of freedom & 28 \\
\cline { 2 - 3 } & Significance & 0.000 \\
\hline
\end{tabular}

From the table above, numerical value of KMO is 0.7, considerably larger than critical value of factor analysis. Meanwhile, the result of sphericity test shows an obvious significance, then we conclude that correlation coefficient matrix is not the unit matrix, thus factor analysis is appropriate.

(2)Factor eigenvalues and extraction of factors 
We use principal component analysis to get factor of eigenfactors and eigenvector by inputting SPSS results (see Table 2)

Table 2 Factor eigenvalues and rate of contribution

\begin{tabular}{|c|c|c|c|}
\hline Factor & Eigen values & Rate of contribution & Accumulated rate of contribution \\
\hline 1 & 3.082 & $37.856 \%$ & $37.856 \%$ \\
\hline 2 & 1.590 & $19.877 \%$ & $57.733 \%$ \\
\hline
\end{tabular}

From Table 2 above, by applying the standard that eigenvalue must be greater than 1 , we can select two factors whose eigenvalue are 3.028 and 1.590 separately, to replace the previous 8 variables. The accumulated rate of contribution of these 2 factors can reach $57.733 \%$.

(3)Structure and naming of the matrix of load of factors

We use Varimax to get the factor loading matrix, i.e. varimax rotation method. (See Table 3)

Table 3 Factor loading matrix by rotating

\begin{tabular}{|c|c|c|}
\hline Variable indicators & \multicolumn{2}{|c|}{ Factors } \\
\cline { 2 - 3 } & 1 & 2 \\
\hline Number of certificated public accountants & 0.879 & -0.146 \\
\hline Registered Capital & 0.805 & -0.163 \\
\hline Organizational form & 0.766 & -0.045 \\
\hline Number of branches & 0.675 & -0.437 \\
\hline Rate of staff with 40-60 years old & -0.486 & 0.694 \\
\hline Staff with bachelor degrees or above & 0.356 & -0.643 \\
\hline Proportion of Non-standard opinions & 0.102 & 0.568 \\
\hline $\begin{array}{c}\text { The proportion of audit fees to the overall operating } \\
\text { revenue in public companies }\end{array}$ & -0.032 & -0.568 \\
\hline
\end{tabular}

Suppose F as the factor extracted, the two factors can be represented as F1, F2 respectively. From the factor loading matrix table after the rotation, we can see that the coefficients of the number of certificated public accountants, registered capital, organizational form and number of branches are $0.879 、 0.805 、 0.766 、 0.675$ separately.

Looking into the features of these variable indicators, we find that coefficients of the rate of the staff with 40-60 years old, proportion of the staff with bachelor degrees or above, proportion of the non-standard opinions and the proportion of audit fees to the overall operating revenue in public companies are $0.694 、-0.643 、 0.568 、-0.568$ separately. Taking features of these variable indicators into consideration, we find that they are associated with the certified public accountants audit independence.

(4)calculations of factor scoring

Applying multiple regression method, we base the coefficient matrix of factors scoring to calculate out the scores of 2 factors: The organizational structure scale and audit independence ( see Table 4)

Table 4 factor score coefficient matrix

\begin{tabular}{|c|c|c|}
\hline \multirow{2}{*}{ Variable indicators } & \multicolumn{2}{|c|}{ factors } \\
\cline { 2 - 3 } & $\begin{array}{c}\text { Organization } \\
\text { structure scale }\end{array}$ & Audit independence \\
\hline Number of certificated public accountants & 0.281 & -0.014 \\
\hline Registered capital & 0.31 & 0.003 \\
\hline Organizational form & 0.294 & 0.326 \\
\hline Number of branches & -0.109 & 0.36 \\
\hline proportion of staff with 40-60 years old & 0.066 & -0.343 \\
\hline Staff with bachelor degrees or above & 0.279 & 0.051 \\
\hline
\end{tabular}




\begin{tabular}{|c|c|c|}
\hline Proportion of Non-standard opinions & 0.096 & 0.345 \\
\hline $\begin{array}{c}\text { The proportion of audit fees to the overall } \\
\text { operating revenue in public companies }\end{array}$ & -0.069 & -0.338 \\
\hline
\end{tabular}

Based on the conclusion of the factor analysis, audit quality contains 2 aspects: one is the variables measuring accounting firm organizational structure scale: numbers of certificated public accountants in accounting firms, registered capital, organizational form and number of branches; The other is variable measuring audit independence: Rate of staff with 40-60 years old, Staff with bachelor degrees or above, Proportion of Non-standard opinions and the proportion of audit fees to the overall operating revenue in public companies.

(5)Discussions on factor analysis

Through factor analysis, we get the standard evaluation system of accounting firms, and found that original variables such as the number of certificated public accountants, registered capital, organizational form, number of braches can all act as factors measuring accounting firms' organization structure scale. These factors have positive interpretation function on audit quality based on the factor score matrix. All these conclusions are in consistency with literature reviews.

But it is also important to note that compared with those in a limited liability form, accounting firms in general partnership form take more responsibilities and risks, thus have better audit quality. From the conclusions of the factor analysis above--in the audit market of China public companies, we use organization structure scale of accounting firms to express the audit quality mainly because accounting firms in general partnership represent larger organization structure.

The results of regression analysis. In view of the low correlation between new variable indicators formed by exploratory factor analysis and the nonexistence of multicollinearity, audit charge can act as dependent variable participating into multivariate regression analysis. In this analysis, all factor scores obtained from exploratory factor analysis act as independent variable, audit charge acts as dependent variable.

We use the total audit fees of public companies audited by accounting firms in 2012 as dependent variable (y), and 2 factors extracted from factor analysis as independent variables: organizational structure scale as independent variable (x1), audit independence as independent variable (x2). After that, we apply the least square method to binary regression analysis, to establish regression model $\mathrm{y}=\mathrm{a} 0+\mathrm{a} 1 \mathrm{x} 1+\mathrm{a} 2 \times 2$.

Based on the results from the analysis above, we get $n(n=44)$ groups $(n=44)$ observation statistics, i.e. $\left(\mathrm{y}_{1}, \mathrm{x}_{11}, \mathrm{x}_{12}\right),\left(\mathrm{y}_{2}, \mathrm{x}_{21}, \mathrm{x}_{22}\right), \ldots . .\left(\mathrm{y}_{44}, \mathrm{x}_{441}, \mathrm{x}_{442}\right)$, then they meet $\mathrm{y}_{\mathrm{i}}=\mathrm{a}_{0}+\mathrm{a}_{1} \mathrm{x}_{1 \mathrm{i}}+\mathrm{a}_{2} \mathrm{x}_{2 \mathrm{i}}$ $+\varepsilon_{\mathrm{i}},(\mathrm{i}=1,2, \ldots . .44)$; Suppose $\varepsilon_{\mathrm{i}}$ follows normal distribution of $(0,1)$ and independent from each other, so the three parameters $a_{0}, a_{1}, a_{2}$ can be evaluated by applying the least square method and the specific formula is as follows:

$$
\begin{aligned}
& \sum y_{i}=n a_{0}+a_{1} \sum x_{1 i}+a_{2} \sum x_{2 i} \\
& \sum x_{1 i} y_{i}=a_{0} \sum x_{1 i}+a_{1} \sum x_{1 i}^{2}+a_{2} \sum x_{1 i} x_{2 i} \\
& \sum x_{2 i} y_{i}=a_{0} \sum x_{2 i}+a_{1} \sum x_{2 i} x_{1 i}+a_{2} \sum x_{2 i}^{2}
\end{aligned}
$$

Through these 3 simultaneous equations we calculate out $\mathrm{a}_{0}, \mathrm{a}_{1}, \mathrm{a}_{2}$.

In SPSS, we apply the model of enter forcing model to take multivariate regression analysis.

Table 5 coefficients of multivariate regression analysis

\begin{tabular}{|c|c|c|c|}
\hline \multirow{2}{*}{ model } & \multicolumn{2}{|c|}{ Unstandardized Coefficients } & \multirow{2}{*}{ standardized Coefficients } \\
\cline { 2 - 3 } & B & Standard error & \\
\hline constant $\left(\mathrm{a}_{0}\right)$ & 5576.763 & 653.142 & \\
\hline Organizational scale $\left(\mathrm{a}_{1}\right)$ & 6868.958 & 660.693 & $0.812^{*}$ \\
\hline Audit independence $\left(\mathrm{a}_{2}\right)$ & -2528.620 & 660.683 & $-0.299^{*}$ \\
\hline
\end{tabular}

Notes: $\mathrm{R}_{1}{ }^{2}=0.75 *$ represents that $\mathrm{p}<0.01$

From the table above, the intrinsic relationship between audit charge and audit quality can be expressed by the following regression model:

$\mathrm{y}($ audit-charge $)=\mathrm{a}_{0}(5576.763)+\mathrm{a}_{1}(6868.958) * \mathrm{x}_{1}($ organization-scale $)-\mathrm{a}_{2}(2528.620) * \mathrm{x}_{2}($ audit-indep endence) 
From the table 5, the explained variation is $75 \%$. Based on standard coefficient, Organizational structure size has positive prediction function on audit charge, and has significance at 0.01 level, that is to say the higher score accounting firms get on the structure of the organization scale, the higher the audit charge is. But audit independence has negative predication function on audit charge, and has significance at 0.01 levels. Thus, the higher score accounting firms get on the audit independence, the lower the audit charge is. The results of regression analysis suggest that audit charge of accounting firms and organization structure scale have a significant positive correlation, while it has a significant negative correlation with audit independence.

By comparing the absolute value of coefficients of the standard organization scale and audit independence, we can get the conclusion that the effect of organization scale on audit charge is far greater than that of audit independence on audit charge. This suggests that audit charge is more easily influenced by organization structure scale than audit independence. Based on the analysis above, audit quality and audit charge are positively correlated.

\section{Conclusion}

After gathering and analyzing over 2,000 audit reports of public companies, and collecting some basic information of accounting firms, the article applied factor analysis and multiple regression method to explore the relationship between audit quality and audit charge, the conclusions are as follows:(1)Audit quality indicators of accounting firms can be classified as accounting firms' structure scale and audit independence;(2)Organization structure scales of accounting firms and audit charge have a significant positive correlation;(3)Audit independence of accounting firms and audit charge have a significant negative correlation.

\section{References}

[1] Copley, Doucet. The Large Audit Firm Fee Premium: A Case of Selectivity Bias?[J]. Journal of Accounting, Auditing and Finance,1993,(17):73-91.

[2] Yao Huaying, Kong Yusheng, Yuan Fenglin. Empirical research on audit charge and audit quality---- based on analysis on Shanghai stock exchange index 180 constituent stock [J]. China Management Informationization, 2010,(04):54-58.

[3] Zhang Shuping, Zhang Kexian. Investigations on audit quality based on accounting firms' audit charge [J].Business accounting,2012,(14):42-43.

[4] Wang Ziqi, He Chucong. Studies on cost and quality in China audit market[J].The economic perspective,2012,(3):87-88.

[5] $\mathrm{Li} \mathrm{Lu} \mathrm{Research} \mathrm{summary} \mathrm{on} \mathrm{audit} \mathrm{quality} \mathrm{of} \mathrm{accounting} \mathrm{firms} \mathrm{[J].Audit} \mathrm{supervision,}$ 2012,(2):21-24.

[6] Xia Yan. Literature review and prospect on the relationship between audit charge and audit quality [J].China securities and Futures, 2012,(05):214.

[7] De Angelo. Auditor Size and Auditor Quality [J].Journal of Accounting and Economic.1981, 183-199

[8] Pittman. J. and Fortin. S. Auditor Choice and the Cost of Debt Capital for Newly Public Firms[J].Journal of Accounting and Economies, 2004, (37): 113-136

[9] Lu Ying. effects of accounting firms' organizational form on audit quality [J].Audit \& Economy Research, 2008,(11): 23-26

[10] Ding Li, Li Minghui, Lv Wei. Personal characteristics of signatured certificated public accountants and audit quality ---- based on empirical studies of data of 2010 public companies [J]. Journal of Shanxi Finance and Economics University, 2012,(08):108-116.

[11] Miao Lianqi. Empirical research on the correlation of auditor gender and audit quality [J]. Chinese Institute of Certified Public Accountants,2012,(11):58-65.

[12] Fu Yun, Wang Dong. Research on the effect of audit charge on audit quality[J].Entrepreneur World, 2011,(6):208.

[13] Sun Li. Studies on China audit market cost and audit quality[J].Green Finance and Accounting, 2006, (7):38-39. 